\title{
Mineral Resources Research Supports Land-Use Planning in the Northern Rocky Mountains
}

\begin{abstract}
The U.S. Forest Service is working to integrate geoscience information into land-use planning processes. To help achieve this goal, U.S. Geological Survey (USGS) Mineral Resource Program scientists are providing a wealth of information, including geologic maps, databases (geology, mineral locality, geochemical, and geophysical), and mineral assessments for the Northern Rocky Mountains of Idaho, Montana, and Washington. This area is known for its world-class deposits of gold, copper, silver, platinum, garnet, and talc and has been the site of a variety of mineral resource assessment studies by the USGS.
\end{abstract}

In the late 1990s, scientists from the U.S Geological Survey (USGS) met with counterparts from the U.S. Forest Service (USFS) to discuss what geologic information was needed from the USGS to support current management objectives for forest lands. The forest plan revision process, planning regulations, and timetables were reviewed and two topics were identified that could be addressed by the USGS. The highest priority need was for a regionally consistent, digital geologic

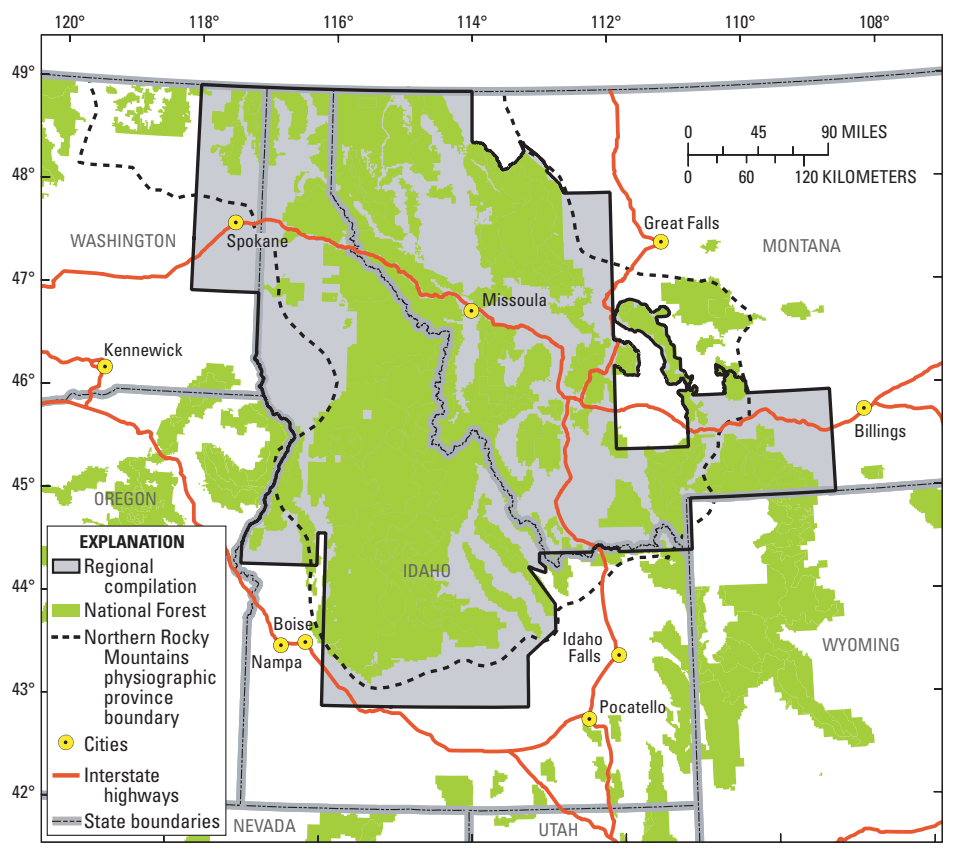

Regional setting of the area of U.S. Geological Survey compilation of digital geologic mapping designed to support U.S. Forest Service goal of integrating geoscience information into landuse planning. ning (scale 1:100,000 to $1: 250,000)$ in the USFS geographic information system (GIS). This product was created from 23 of those maps were already in a digital format; the others were available only ate for regional plandigital versions of 43 geologic maps. Only as printed maps. Working with state agencies, the USGS converted the remaining printed maps to a digital format. The maps used included new geologic maps for the Salmon and Payette National Forests and several 100,000-scale quadrangle maps published by the USGS and the Idaho Geological Survey. Integrating these various maps into one was challenging because they used different standards and included inconsistencies across political boundaries, which made interpretation of the geology difficult and time consuming. Consequently, the datasets were reviewed and extensive revisions were made to provide the information in consistent, accessible, and user-friendly formats to maximize their usefulness to the USFS.

Minerals information.-Regional datasets and studies of areas with mineral potential will help the USFS understand where future minerals-related activities may take place. Besides geology, regional datasets include the locations of active mines and significant mineral deposits and geophysical datasets that provide information about the distribution of rocks beneath the surface. USGS scientists and collaborators studied the large, undeveloped copper deposits in northern Idaho and northwestern Montana and copper-cobalt deposits in Idaho. 
Other studies looked at the relation between mineral deposits and the locations of ancient faults and at the geochemistry of mined and unmined geologic terrains.

Collaborative research has been an important part of this endeavor. The digital geologic map includes information collected through cooperative research agreements with the Idaho Geological Survey and the Montana Bureau of Mines and Geology. Cooperative studies of geology and forest management with the University of Idaho and USFS Rocky Mountain Research Station, Moscow, influenced the design of the digital geologic map database. The USGS, the USFS, and the University of Montana worked together to compile data on garnet resources in northern Idaho. Contracts with exploration geologists provided access to private-sector exploration data on copper and lead-zinc mineralization hosted by sedimentary rocks. Data on mining claims and on minerals-related permits were compiled with the cooperation of the USFS and U.S. Bureau of Land Management.

The resulting information is being used by the USFS to model different scenarios relating to land use, forest health, and landslide and wildfire hazards, as well as for the assessment of the mineral resource potential, which is critical to planning future mineral exploration and mining in the forests. The final datasets generated by this project provide the ability to combine different datasets so that planning can, in the words of one USFS manager, "provide the best solutions to problems of all types."

Because the amount of technical information about the Northern Rocky Mountains was overwhelming, USGS scientists provided

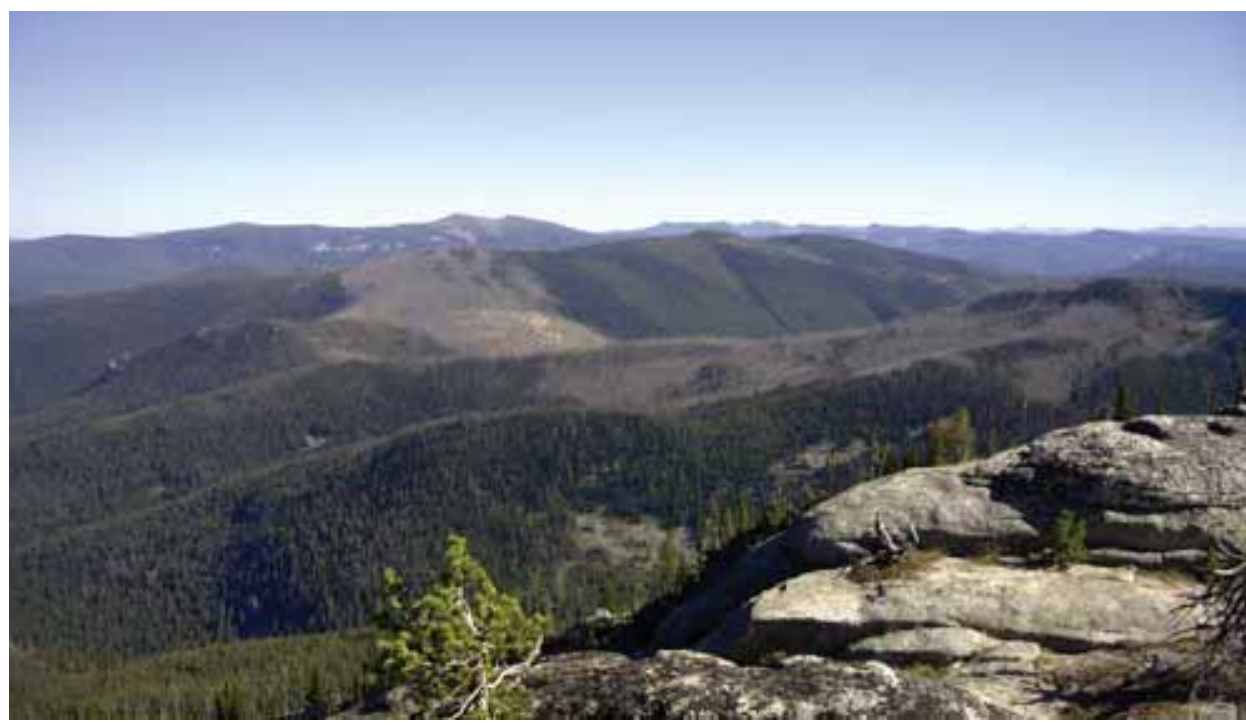

Burnt Knob in the Bitterroot Mountains of northeastern Idaho (foreground) and forest-fire scar along ridge crossed by the Nez Perce Trail. This area contains critical habitat for threatened and endangered species, such as grizzly bears, salmon, and bull trout, posing land-use management issues that are supported by new digital datasets from the U.S. Geological Survey. (USGS photograph by Arthur A. Bookstrom.)

interpretive summaries of the different datasets to facilitate their usefulness in the forest planning process. For example, the 2,100 map units in the digital geologic map compilation are difficult to understand and illustrate; the USGS provided information for each unit that allows derivative maps to be constructed based simply on rock type-an example is the generalized geologic map shown below. The new digital datasets have enabled USFS managers to analyze huge amounts of geologic, geochemical, geophysical, and mineral-locality information over the entire project area at consistent map scales with relative ease.

The information in geologic datasets have long been used to understand Earth history; assess mineral, energy, and water resources;

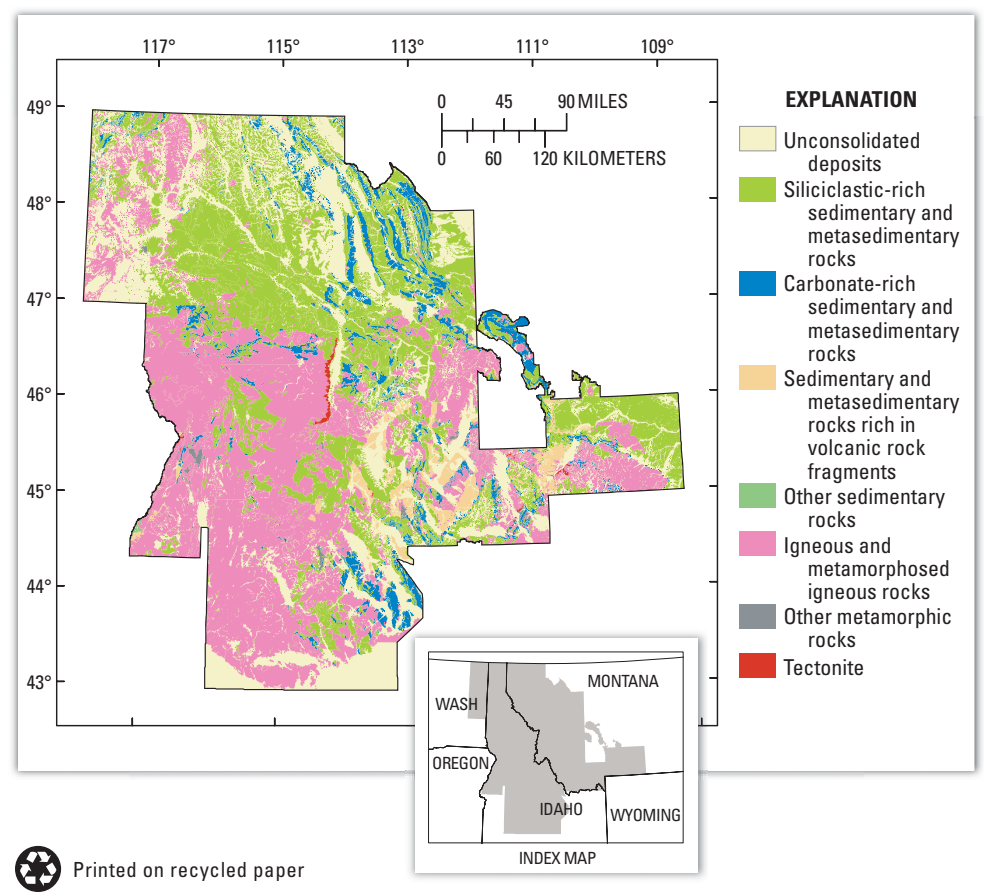

Recent digital compilation of geologic datasets allowed U.S. Geological Survey scientists to generate this generalized geologic map of the Northern Rocky Mountains. The information in the dataset can be used to understand Earth history; assess mineral, energy, and water resources; and delineate hazards related to Earth processes. Datasets can be combined with other information to produce ecological units, key to U.S. Forest Service forest management. and delineate hazards related to Earth processes. The same information in the new digital format can now be used more easily by USFS planners to help delineate ecological units based on landform, rock type, soil, and vegetation (such as land type associations) or disturbance regimes (areas that would have similar response to disturbances such as fires, road construction, and timber harvest). The ability to combine different datasets will allow a better understanding of the relation between geology and ecosystems and will support decisions about threatened and endangered species, as well as future mineral exploration and development.

Michael L. Zientek and Susan J. Kropschot

Edited by Peter H. Stauffer

Graphic design by Susan Mayfield

COOPERATING ORGANIZATIONS

Idaho Geological Survey

Montana Bureau of Mines and Geology University of Idaho University of Montana

U.S. Bureau of Land Management U.S. Forest Service

For further information, contact: U.S. Geological Survey

904 W. Riverside Avenue, Room 202 Spokane, WA 99201-1087 (509) 368-3105

Email:mzientek@usgs.gov

For the digital geologic map, see U.S. Geological Survey Open-File Report 2005-1235 (available online at http://pubs.usgs.gov/of/2005/1235)

For more information on other related products, see U.S Geological Survey Open-File Report 2005-1382 (available online at http://pubs.usgs.gov/of/2005/1382 )

This Fact Sheet and any updates to it are available online at http://pubs.usgs.gov/fs/2005/3155

For additional information visit: http://minerals.usgs.gov/ 